\title{
THE COMPARATIVE ANALYSIS OF REAL ESTATE MARKET DEVELOPMENT TENDENCIES IN THE BALTIC STATES
}

\author{
Inese BINOVSKA ${ }^{1}$, Linda KAUŠKALE ${ }^{2}$, Jānis VANAGS ${ }^{3}$ \\ ${ }^{1}$ RIX Technologies, Riga, Latvia \\ ${ }^{2,3}$ Institute of the Civil Engineering and Real Estate Economics, \\ Riga Technical University, Riga, Latvia \\ Corresponding author's e-mail: Linda.Kauskale@rtu.lv
}

\begin{abstract}
The development of the real estate market contributes to the development of the national economy, thus creating a favourable investment climate for the investors. Increase in the level of the incomes of the inhabitants may increase the availability of housing in the country by fiscal and monetary policy instruments. The topicality of the paper is related to the need for analysis of the trends and prospects of the real estate market development of the Baltic States, as it has a high social meaning and has a high importance for market participants. The objective of the research is to analyse influencing factors and tendencies of real estate market development in Baltic States, and includes a comparative analysis of the residential property market in the Baltic States is conducted. The research methods used in the paper are statistical data analysis, historical and logical approach methods. The article focuses mainly on the housing market. It was concluded in the study that under the similar geographic and economic conditions in the Baltic States, the housing affordability index and real estate market development tendencies have many differences and success indicators are still varying.
\end{abstract}

Keywords: Baltic States, development, housing affordability, real estate market, residential real estate.

\section{INTRODUCTION}

By raising the housing affordability index, the state would have the opportunity to attract investors to the real estate market, which would contribute to the high-quality housing supply, thus creating an appropriate solvent demand. The contribution of the investors promotes the development of the real estate market of any country. The objective of the research is to analyse influencing factors and tendencies of real estate market development in Baltic States, and includes a comparative analysis of the residential property market in the Baltic States is conducted. The research methods used in the paper are statistical data analysis, historical and logical approach methods. The object of the research is the real estate market development in Baltic States. The subject of the study is the housing segment of the real estate market in the Baltic States.

Initially, real estate was used as a housing and business object; however, with the course of time and with the increasing needs and wishes of people, real estate 
has become an investment object both for individuals and legal entities. Real estate is one of the production factors and the object for residential purposes (residential houses, cottages, etc.) as well. Real estate, which is the basis of the national wealth of any country, can be considered as the backbone of the market economy. Thus, the real estate market development has a significant role in several sectors of the economy. The stability of the national economy is dependent also on the real estate market development, therefore its research and analysis is a topical issue.

Real estate market is being influenced by several factors. The real estate market development tendencies in the Baltic States, and in Latvia in particular, are analysed further in the article.

\section{OVERVIEW OF REAL ESTATE MARKET DEVELOPMENT AND ITS INFLUENCING FACTORS IN THE BALTIC STATES}

In order to assess the situation in the real estate market of the capitals of the Baltic States, the Housing Affordability Index should be considered as one of the factors influencing the development of this market.

The Housing Affordability Index shows to each country how and why the availability of housing acquisitions has changed. The Housing Affordability index can be descripted as follows:

"The Housing Affordability Index represents the maximum number of $\mathrm{m}^{2}$ that may be purchased by middle class residents by using bank loans and without excessive risk (maturity of up to 25 years, initial payment of $20 \%$ of the value of the real estate and $30 \%$ of the income on credit payments)" (Rudzitis, 2016).

And Swedbank Housing Affordability Index is explained as follows:

"The index is the ratio of actual income to the norm. If the index is 100 points, the households use $30 \%$ of their net wages for mortgage costs. If the index is higher than 100 points, the household purchasing power exceeds the established rate. If the index is less than 100 points, the household purchasing power is lower than the established rate" (Šečkute, Semjenovs \& Isküll, 2016).

Four factors that are affecting the housing market are taken into account in the calculation: real estate prices, personal income, inflation, and changes in the interest rates on loans. According to Šečkute, Semjenovs \& Isküll (2016), the Housing Affordability Index is calculated according to the formula:

where

$$
\begin{gathered}
M P I=\frac{A v \cdot \text { inc. }}{N . \text { inc. }} \cdot 100, \\
\text { N.inc. }=\frac{H K M}{0.3},
\end{gathered}
$$

MPI - Housing Affordability Index;

Av.inc. - average net salary (1.5 months), EUR;

$N . i n c$. - net salary, which fulfils the conditional norm, EUR;

$H K M$ - mortgage loan payment, EUR. 
When calculating the Housing Affordability Index, analysts take into account the following variables (Šečkute et al., 2016):

- three-month average housing price in the relevant city;

- size of the housing;

- monthly income of the household is equivalent to average net salary for 1.5 months received in the same city;

- interest rate - three-month average effective annual interest rate (including interest and other related costs) for the new housing loan issued to the household in EUR currency;

- first deposit and maturity of the mortgage loan.

In spite of the decrease in the index, the Housing Affordability Index in Riga is still higher than in Tallinn and Vilnius: at the end of the first quarter of this year, it was $50.8 \mathrm{~m}^{2}$ in Riga, $43.2 \mathrm{~m}^{2}$ in Tallinn, and $40.9 \mathrm{~m}^{2}$ in Vilnius. Although housing availability index in Riga is the highest for standard-type apartments, the residents of Tallinn have the potential to have the best opportunity to acquire their own housing, because the time required to collect the first deposit is the shortest (Rudzìtis \& Martinsone, 2015). In the second quarter of 2016, the Housing Affordability Index (the quantitative Housing Affordability Index, taking into account the influence of four factors - apartment prices, wages, interest rates, and consumer prices) in standard-type apartments in Riga increased to $52.2 \mathrm{~m}^{2}$, which is by $0.2 \mathrm{~m}^{2}$ higher than in the 1st quarter of 2016 and by $0.3 \mathrm{~m}^{2}$ higher than in the 2nd quarter of 2015 (Rudzītis, 2016).

The value of the Housing Affordability Index for new housing has slightly different trends. According to the same research, Housing Affordability Index has rapidly decreased in Tallinn in the 2 nd quarter of 2016, while the value of the index in Vilnius has decreased because the housing prices have increased more rapidly than real incomes.

The most significant characteristics of real estate are the mandatory necessity for all market participants to use it economically in the following way (Vanags, 2010):

- households in order to provide the elementary living conditions - each individual needs a roof over the head;

- businessmen - to conduct business. The largest number of all types of commercial activity is wholly or partially related to the necessary structures and land plot;

- the state needs both buildings and special structures and relatively large areas to carry out national defence and public order supervision as well as other functions;

- in order to achieve the statutory objectives, the public organizations require the buildings, structures, and adjacent or stand-alone land plots.

Real estate market development influencing the supply and demand factors is shown in Table 1. 
Table 1. Real estate market development influencing the supply and demand factors - model (table made by authors)*

\begin{tabular}{|c|c|}
\hline Factors affecting demand & Factors affecting supply \\
\hline Inhabitant income & Real estate price level \\
\hline Current living conditions & Profitability of the industry \\
\hline Education level & Yield in the sector, capitalization rates \\
\hline Life experience & Construction material costs \\
\hline Occupation & Energy prices \\
\hline Culture and traditions & Design costs \\
\hline Health state & Construction technologies \\
\hline Marital status & Construction industry capacities \\
\hline Subjective factors & $\begin{array}{l}\text { Taxes (real estate tax, value added tax, income } \\
\text { tax, etc.) }\end{array}$ \\
\hline Inhabitant attitude towards the environment & Wage level in the sector \\
\hline Fiscal policy & Quantitative changes in labour \\
\hline Monetary policy & Accessibility of land \\
\hline $\begin{array}{l}\text { Macroprudential policy (credit policy } \\
\text { adjustment) }\end{array}$ & Land acquisition costs \\
\hline National demographic status change & Expected process and delivery deadlines \\
\hline State economy development cycle phase & Zoning \\
\hline Real estate market cycle phase & Construction industry business cycle phase \\
\hline Future expectations of potential buyers & Competition level in the construction industry \\
\hline Alternative investment yield opportunities & State economy development cycle phase \\
\hline $\begin{array}{l}\text { Availability of mortgage loans (interest } \\
\text { rates and provisions) }\end{array}$ & Real estate market cycle phase \\
\hline Management costs & $\begin{array}{l}\text { Increase or decrease in the income of market } \\
\text { participants }\end{array}$ \\
\hline Taxes (real estate tax, income tax, etc.) & National monetary policy \\
\hline GDP growth & $\begin{array}{l}\text { Fiscal policy, National competition policy } \\
\text { Macroprudential policy (credit policy } \\
\text { adjustment) }\end{array}$ \\
\hline \multicolumn{2}{|c|}{ Future forecasts of the market participants and other factors } \\
\hline
\end{tabular}

* Factors were updated based on (Vanags, 2010). 
One of the demand analysis examples shows that the number of people aged 25 to 35 is unusually large in the largest cities of the Baltic States, and they could be even more active in the real estate market. Thus, it can be predicted that in the next 5 to 10 years it will be "as good as it can be" (Baltic Sotheby's International Realty, 2015). Real estate prices can significantly influence decisions of buyers. Real estate prices can change under the influence of all real estate supply and demand influencing factors. Real estate price changes appear as a result of the previously mentioned developed factorial influence. Next part analyses the real estate market development tendencies in the Baltic States and in Latvia in particular.

\subsection{Comparison of the Real Estate Market Development in the Capitals of the Baltic States}

Current subchapter provides the overview of real estate market development tendencies in Baltic States. The prices for new apartments in Tallinn and Vilnius increased faster than in Riga, and the Housing Affordability Index for new housing in Tallinn decreased, as the rapid increase in the prices of apartments in the new projects has been observed over the year 2015. The average prices for new housing in Riga have not changed over a year, which also explains the increase in the value of the index. In addition, the further decline in credit interest rates had further positive impact on the growth of the index in Riga (Rudzitis, 2016). According to the research of Rudzitis (2016), the beginning of 2016, the average loan interest rates for new housing credits in Latvia have decreased by 0.20 percentage points, but in Estonia, credit rates were by 0.05 percentage points lower in the 2nd quarter of 2016, while in Lithuania they were by 0.03 percentage points higher than in the last quarter of 2015. In the second quarter of 2016, the effective housing credit interest rate remained the lowest in Lithuania (2.06\%), followed by Estonia (2.60 \%) and Latvia (3.28 \%).

One of the biggest obstacles to the acquisition of housing in Riga is the first deposit. In turn, the ALTUM program may only be used by young families, which, of course, contributes to the real estate market development.

The inhabitants of Tallinn, who receive an average salary and save $30 \%$ of their income, would need 25 months to collect the first deposit of $20 \%$ in order to acquire a $40 \mathrm{~m}^{2}$ single-room standard-type apartment, the inhabitants of Riga would need 26.5 months, while the inhabitants of Vilnius would need 29.3 months. By analysing the household incomes, it can be concluded that they have increased in all three Baltic countries in 2015. The real average wage (average net wage taking into account the changes in consumer prices) increased by $7.4 \%$ in Latvia, by $6.9 \%$ in Estonia, and by $6 \%$ in Lithuania. The increase in household incomes has contributed to the increase in demand for housing and consumer credits. The amount of newly issued housing credits in Lithuania has increased by $21 \%$ in 2015 compared to 2014, in Estonia - by $15 \%$, and in Latvia - by $9 \%$ (Rudzītis, 2016).

The increase in the amount of issued housing credits contributes to the increase in demand in the real estate market, in the increase in the number of 
transactions and to the development of the real estate market. Key office figures in the Baltic States in 2017Q1 and prime yields in the Baltic States by country are shown in Tables 2 and Table 3.

Table 2. Key office figures in the Baltic States in 2017Q1

(Colliers International, 2017a)

\begin{tabular}{|c|c|c|c|}
\hline Class & Tallinn & Riga & Vilnius \\
\hline A Class Rents & 12.5 to 16.2 & 13.0 to 16.0 & 13.5 to 16.5 \\
\hline B1 Class Rents & 8.5 to 13.5 & 9.0 to 12.0 & 9.0 to 13.5 \\
\hline A Vacancy*, \% & $4 \%$ to $5 \%$ & $14 \%$ to $16 \%$ & $3 \%$ to $4 \%$ \\
\hline B1 Vacancy*, \% & $7 \%$ to $8 \%$ & $6 \%$ to $7 \%$ & $7 \%$ to $8 \%$ \\
\hline
\end{tabular}

$\mathrm{EUR} / \mathrm{m}^{2}$ per month, ${ }^{*}$ speculative office market vacancy rate.

Table 3. Prime yields in the Baltic States by country in $1^{\text {st }}$ half year 2017 (Colliers International, 2017b)

\begin{tabular}{|l|r|r|r|}
\hline Prime Yields & \multicolumn{1}{|c|}{ Estonia } & \multicolumn{1}{c|}{ Latvia } & \multicolumn{1}{c|}{ Lithuania } \\
\hline Office & $6.25 \%$ & $6.75 \%$ & $6.50 \%$ \\
\hline Retail & $6.50 \%$ & $6.75 \%$ & $6.50 \%$ \\
\hline Industrial & $7.75 \%$ & $8.00 \%$ & $8.00 \%$ \\
\hline
\end{tabular}

The highest prime yields in the Baltic States are the yields in industrials sectors in Latvia and Lithuania. The highest indicators of the vacancy of A Class buildings in 2017 1HY were observed in Riga, lowest indicators - in Lithuania. At the same time, Riga demonstrates the lowest vacancy rates for B1 Class buildings in the Baltic States. In 2017 1HY, Estonia had the lowest prime yields for office, retail and industrial buildings, in comparison to other countries. Next three subparts include real estate market development tendencies in each capital of Baltic States in particular.

\subsection{Analysis of Real Estate Market Development in Lithuania}

In 2015, the main price rise was observed in the segment of apartments in the capital of Lithuania, Vilnius; however, the apartment prices in 2015 are slightly lower compared to the prices of apartments in 2014.

Apartment prices in Vilnius have risen by $3.6 \%$ in 2015. As a result, the average price increased to $1.326 \mathrm{EUR} / \mathrm{m}^{2}$ at the end of 2015 (Fig. 3). Since the last lowest price level in May 2010 until December 2015, the apartment prices have risen by $14.9 \%$ (to $172 \mathrm{EUR} / \mathrm{m}^{2}$ ). In 2015, the prices of new project apartments increased by $3.9 \%$ (Ober-Haus Real Estate Advisors, 2016). In 2015, the prices of new project apartments in the residential areas increased by almost $4.0 \%$ and ranged from $920 \mathrm{EUR} / \mathrm{m}^{2}$ to $1650 \mathrm{EUR} / \mathrm{m}^{2}$ at the end of the year. In the city center and in the Old Town, the apartment prices ranged from $1050 \mathrm{EUR} / \mathrm{m}^{2}$ to $1800 \mathrm{EUR} / \mathrm{m}^{2}$ and the renovated apartment prices ranged from $1450 \mathrm{EUR} / \mathrm{m}^{2}$ to $3500 \mathrm{EUR} / \mathrm{m}^{2}$ per square meter (Ober-Haus Real Estate Advisors, 2016). Similar 
to Latvia, the apartment prices depend on the prestige of the residential areas - in the most prestigious districts of Lithuania (Antakalnis, Naujamiestis, Žverrynas), the prices of old apartments ranged from $900 \mathrm{EUR} / \mathrm{m}^{2}$ to $2300 \mathrm{EUR} / \mathrm{m}^{2}$. In contrast, the prices of new project apartments ranged from $1400 \mathrm{EUR} / \mathrm{m}^{2}$ to $2300 \mathrm{EUR} / \mathrm{m}^{2}$ (Ober-Haus Real Estate Advisors, 2016).

The development of the real estate market in the residential segment in 2015 was very active. The number of transactions increased by $16 \%$ compared to 2014 , and on average, 810 sales transactions with apartments and 70 sales transactions with private houses were handled each month (Ober-Haus Real Estate Advisors, 2016).

In Lithuania, the market participants - buyers - were offered a very large range of new project apartments as well as low mortgage rates, and the increase in income was projected.

\subsection{Analysis of Real Estate Market Development in Estonia}

Real estate market in Estonia after the crisis has been able to recover in a couple of years, moreover - in all segments of the real estate, therefore, unlike in Latvia, it demonstrates the signs of stable development and allows the market participants to look with confidence in the future.

In 2015, the Estonian real estate market continued to grow, but the growth was not very rapid. The transactions in the housing market were active, which was promoted by a favourable policy of banks - low interest rates similar to those of pre-crisis, and they were beneficial also to the mortgage borrowers who continue to cover their liabilities.

In 2015, the average price of apartments in Tallinn increased by $3.8 \%$ and was $1556 \mathrm{EUR} / \mathrm{m}^{2}$. In December 2015, the number of real estate transactions increased by $16 \%$. The prices of old standard-type apartments in the residential areas were stabilized, while the prices of new project apartments increased by $10 \%$ to $15 \%$. In turn, in 2016, the average price for apartments in Tallinn increased by $12.2 \%$ and reached 1746 EUR per square meter in December 2016 (Ober-Haus Real Estate Advisors, 2016). One of the reasons for the increase in the apartment prices was not only the low interest rates but also the increase in wages, which made it possible for the inhabitants to get a loan for the acquisition of apartments. The inhabitants in Estonia consider energy efficiency (lower heating costs) as one of the main reasons for the acquisition of real estate, thus the demand is higher for new project housings.

As one of the reasons for the high apartment prices is the low interest rate on mortgage loans. With the increase in income, people are willing to invest in the acquisition of apartments that can be further rented out or used for their own needs. In 2015, $40 \%$ of real estate transactions in Estonia took place without a mortgage loan. The prices of new project apartments reached $2200 \mathrm{EUR} / \mathrm{m}^{2}$ to $5000 \mathrm{EUR} / \mathrm{m}^{2}$ in the city center and $1500 \mathrm{EUR} / \mathrm{m}^{2}$ to $2200 \mathrm{EUR} / \mathrm{m}^{2}$ in the suburbs (Ober-Haus Real Estate Advisors, 2016). Also, in 2016, $40 \%$ of transactions took place without a bank loan, and $10 \%$ to $20 \%$ of the apartments in total were acquired as an investment. The prices of new project apartments reached 
$2300 \mathrm{EUR} / \mathrm{m}^{2}$ to $5000 \mathrm{EUR} / \mathrm{m}^{2}$ in the city center and $1500 \mathrm{EUR} / \mathrm{m}^{2}$ to $2200 \mathrm{EUR} / \mathrm{m}^{2}$ in residential areas. The apartment prices in Estonia are fluctuating, mainly due to their location. Most of transactions in 2016 were in the city center, and the apartments in good condition or in the renovated buildings were mostly demanded, with the prices from $2000 \mathrm{EUR} / \mathrm{m}^{2}$ to $2900 \mathrm{EUR} / \mathrm{m}^{2}$ (Ober-Haus Real Estate Advisors, 2017).

Currently, the development of the real estate market in Estonia is the most active in comparison with Latvia and Lithuania due to low interest rates on mortgage loans and the increase in the level of people's income as well as the active policy of attracting investors in the neighbouring country. The increase in the Housing Affordability Index in Tallinn is observed for old apartments, while the Housing Affordability Index for the apartments in new projects has decreased.

\subsection{Real Estate Market Development of Residential Areas in Latvia}

By analysing the activity of local buyers in the residential segment of new projects in 2016, it can be concluded that the activity of local buyers has increased by $42 \%$. Overall, 120-130 transactions on average took place in the new apartments in Riga per month. The prices for new project apartments in the residential areas were ranging on average from $1000 \mathrm{EUR} / \mathrm{m}^{2}$ to $1750 \mathrm{EUR} / \mathrm{m}^{2}$, and in the center of Riga - from $1450 \mathrm{EUR} / \mathrm{m}^{2}$ to $3800 \mathrm{EUR} / \mathrm{m}^{2}$. The buyers were mostly interested in small 2 to 3 room apartments with full furnishing (Balsts, n.d.). The number of real estate transactions in 2016 increased by $10.5 \%$ in comparison with 2015 . The mortgaging volume increased, and almost every third acquisition was made by using the ALTUM State Support Program for young families with children. According to the research by Balsts (n.d.), the average prices of standard-type apartments have increased by $6.5 \%$ since the beginning of 2016. Real estate market development of residential area in standardtype apartment segment, the segment of new apartment projects and the segment of private houses in Latvia are analysed in the next three subparts.

\subsection{Standard-type Apartment Segment}

The decline in the supply of standard-type apartments is one of the most important factors. In the last quarter of 2015, the market activity has slightly declined, because after a dramatic increase by almost $20 \%$ in the third quarter, the decline by $3.1 \%$ was observed, but compared with the fourth quarter of 2014 , the number of transactions declined by $2.9 \%$ (Latio, 2016).

The fall in market activity in the fourth quarter of 2015 can be explained by the fact that some of the sellers have withdrawn the potential apartments from active trading and the apartments were rented out for "winter" period, thus reducing the expenses at the expense of utility invoices. Similarly, the potential buyers of standard-type apartments continued to have relatively low solvency and little savings for the first deposit, which contributed to the rental market.

The price range for the apartments in the residential areas in Riga was still very diverse - both in line with the market situation by reaching $450 \mathrm{EUR} / \mathrm{m}^{2}$ to $700 \mathrm{EUR} / \mathrm{m}^{2}$ and not in line with the market conditions, by ranging from 
$800 \mathrm{EUR} / \mathrm{m}^{2}$ to $1000 \mathrm{EUR} / \mathrm{m}^{2}$. In turn, the standard-type apartment prices increased by $0.3 \%$ in December 2016. The average price of standard-type apartments in December reached $705 \mathrm{EUR} / \mathrm{m}^{2}$, and since the beginning of 2016, standard-type apartment prices have generally increased by $7.6 \%$ (Ober-Haus Real Estate Advisors, 2015).

Local buyers are also interested in the larger three- and four-bedroom apartments in the renovated buildings with an average price of up to 150000 EUR. However, the supply that meets the requirements of the buyers is relatively low, because only qualitatively renovated apartments in renovated buildings with autonomous gas heating and elevators are considered. As there is no sufficient supply of three- and four-room apartments in the renovated houses, the largest number of transactions in 2016 took place with two- and three-room standard-type apartments with an area of $40 \mathrm{~m}^{2}$ to $60 \mathrm{~m}^{2}$ (Ober-Haus Real Estate Advisors, 2015).

In turn, two thirds of all transactions with standard-type apartments took place in eight of the most demanded neighbourhoods in Riga in 2015, with the ratio remaining almost unchanged since 2014. According to Latio (2016), compared with the previous year, the market activity growth by $10 \%$ was observed in Iḷguciems, but in Imanta, Vecmīlgrāvis and Ziepniekkalns the activity decreased by $12 \%$ to $15 \%$.

\subsection{The Segment of New Apartment Projects}

The activity growth in the new apartment segment continued in the fourth quarter of 2015 . The activity increased by $18 \%$ during the year, thus turning the year to the year of growth in this segment. In turn, the local buyer's activity increased by $42 \%$ in the segment of new projects in 2016. A total of 120-130 transactions per month took place in Riga on average (Latio, 2016). In turn, prices for new project apartments in residential areas were ranging from $1000 \mathrm{EUR} / \mathrm{m}^{2}$ to $1750 \mathrm{EUR} / \mathrm{m}^{2}$ on average, in the center of Riga - from $1450 \mathrm{EUR} / \mathrm{m}^{2}$ to $3800 \mathrm{EUR} / \mathrm{m}^{2}$. In the first half of 2016, in total, 575 transactions were registered, which was by $2 \%$ less than in the first half of 2014, when 587 transactions were carried out, and by $29 \%$ more than in the first half of 2015 (Balsts, n.d.). In the 4th quarter of 2016, there was a slight increase in non-resident activity in the new apartment market, which made $17 \%$ of the total number of transactions (Latio, 2016).

Similarly, in the 1st quarter of 2016, the number of transactions with apartments, the price of which exceeded the minimum threshold for obtaining a temporary residence permit (250 000 EUR), reached a record high level of 32 transactions (Arco Real Estate, n.d.). In turn, in the 2nd quarter of 2016, 25 transactions were concluded similar to the second and third quarters of 2015. By analysing the largest number of offers in the new apartment market in 2015, the largest number of offers was in Pḷavnieki, Ziepniekkalns, and Āgenskalns, while the smallest offer was in Kengarags, Vecmīlgrāvis, and Bolderāja. In 2016, the largest number of offers was in Purvciems and Āgenskalns, while the smallest - in Čiekurkalns and Kengarags (Arco Real Estate, n.d.). The number of offers in each 
neighbourhood depends on the demand of the market participants. A significant factor for the market participants is not only the acquisition of housing but also the location of the apartment, the condition of the apartment (whether renovated or not), the development of the infrastructure in the residential area.

\subsection{The Segment of Private Houses}

By analysing the segment of the real estate market of private houses, we have to conclude that it is characterized by a complete reorientation and adaptation to the requirements of the local market in 2015. In Riga, 23 transactions with private houses took place on average, which is by 5-10 transactions less than in the previous year (Latio, 2016). In the 2nd quarter of 2015, compared to the corresponding period of 2014, the private house market decreased by $41 \%$ in terms of transactions and by $33 \%$ in terms of the total amount. In the segment of private houses in the fourth quarter of 2015 , the market decreased by $13 \%$ by the number of transactions and by $22 \%$ by the transaction amount (Latio, 2016). The rapid decline in the number of transactions took place in the last months of the 2015, and the total amount decreased by half in November. In turn, at the beginning of 2016, there was a record number of transactions with private houses, but in the fourth quarter, the number of transactions decreased by $30 \%$ (Latio, 2016). This rapid decline in the number of transactions can be explained differently, but one of the factors is the end of the year, when the market participants-buyers have other expenses related to the upcoming holidays as well as higher utility costs.

By comparing the amount of transactions in the fourth quarter of 2016 with the corresponding period of 2015 , it increased by $49 \%$. In 2016, the increase in the number of transactions by $80 \%$ was observed with the houses at a price over 100000 EUR (Latio, 2016). By acquiring a private house, the buyers evaluate their financial position and the time resources to understand whether to buy a repaired or renovated house. The buyers pay great attention to the quality of the buildings, to the surrounding infrastructure, to the nearby traffic, and to the availability of the necessary engineering communications on the land plot. The data show that $40 \%$ of buyers buy private houses at a price of more than 50000 EUR (Latio, 2016). Real estate market development trends in Latvia and Baltic states are analysed in the next part.

\section{REAL ESTATE MARKET DEVELOPMENT TRENDS IN LATVIA AND BALTIC STATES}

The analysis of real estate market development tendencies is an important part of economic development analysis. As was researched previously (Geipele et al., 2014), according to the research by Eddie C. M. Hui and Ka Kwan Kevin Chan (2014), during a financial crisis, correlation of a type of asset market between two countries usually increases, i. e., they either move up together or, more commonly, move down together. This regularity is presented by the example of Figure 1, where the cyclical nature of an unbalanced development of the real 
estate price dynamics and house price indices in European countries from 2006 to 2016 can be observed.

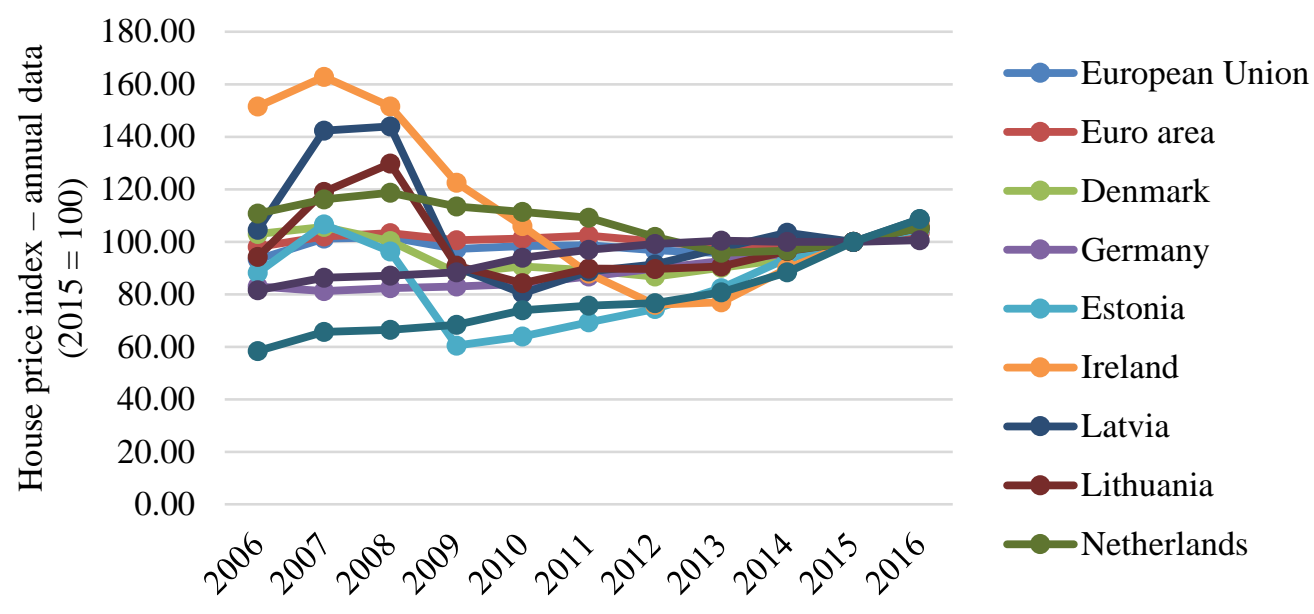

Fig. 1. House price index, $2015=100$. Data: Eurostat (n.d.).

(Figure made by authors)

The housing price index in the Baltic States is shown in Fig. 2.a and Fig. 2.b.

a)

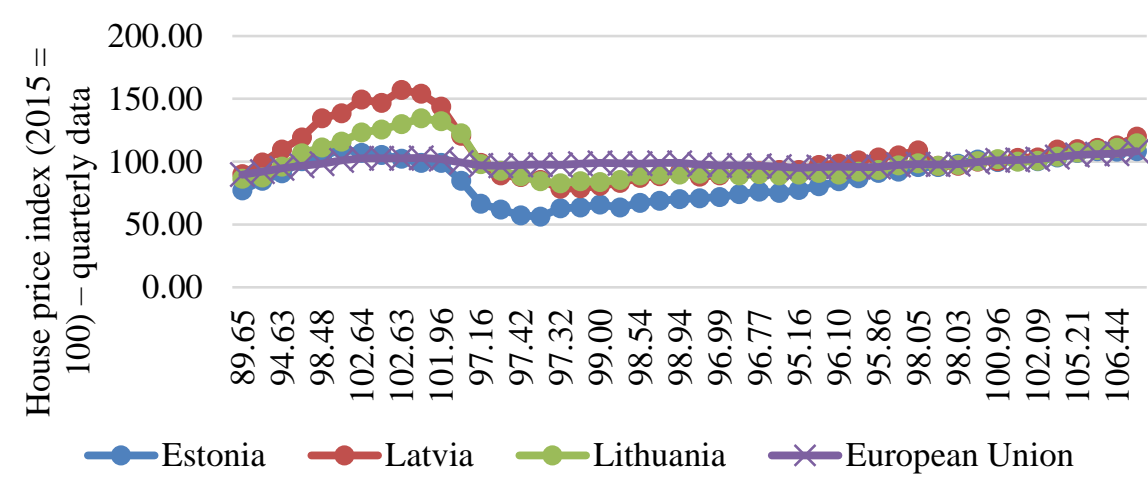

b)

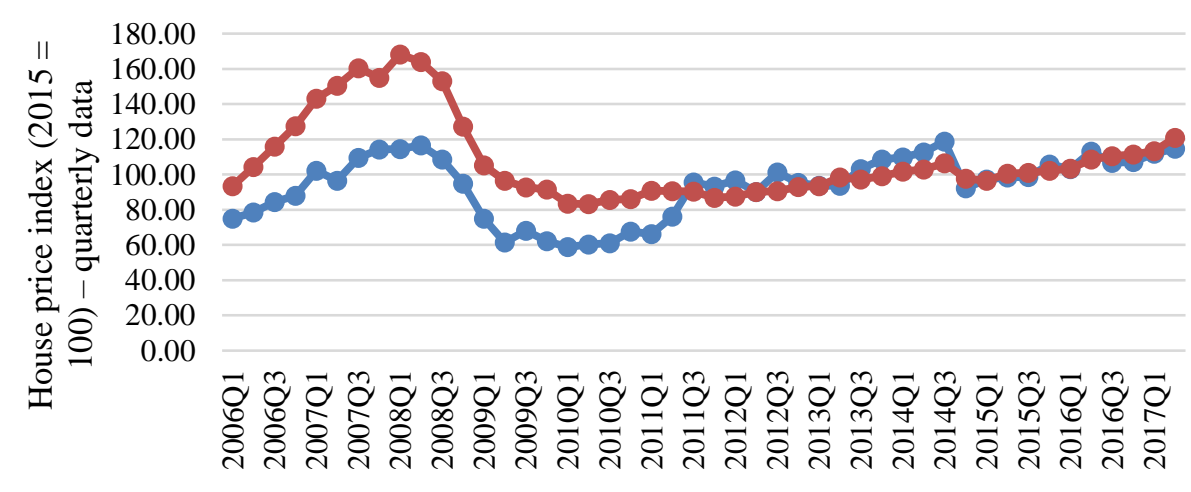

$\longrightarrow$ New dwellings $\longrightarrow$ Existing dwellings

Fig. 2.a. Housing price index, $2015=100$, quarterly data. Data: Eurostat (n.d.) Fig. 2.b. House price index for new and existing dwellings. Data: Eurostat (n.d.). (Figures made by authors) 
For construction industry development, expectations of developers and construction confidence indicators have special importance. Fluctuations on real estate market result in profit or losses. The profit or loss of merchants (commercial companies) by quarters by the kind of activity is illustrated in Fig. 3.

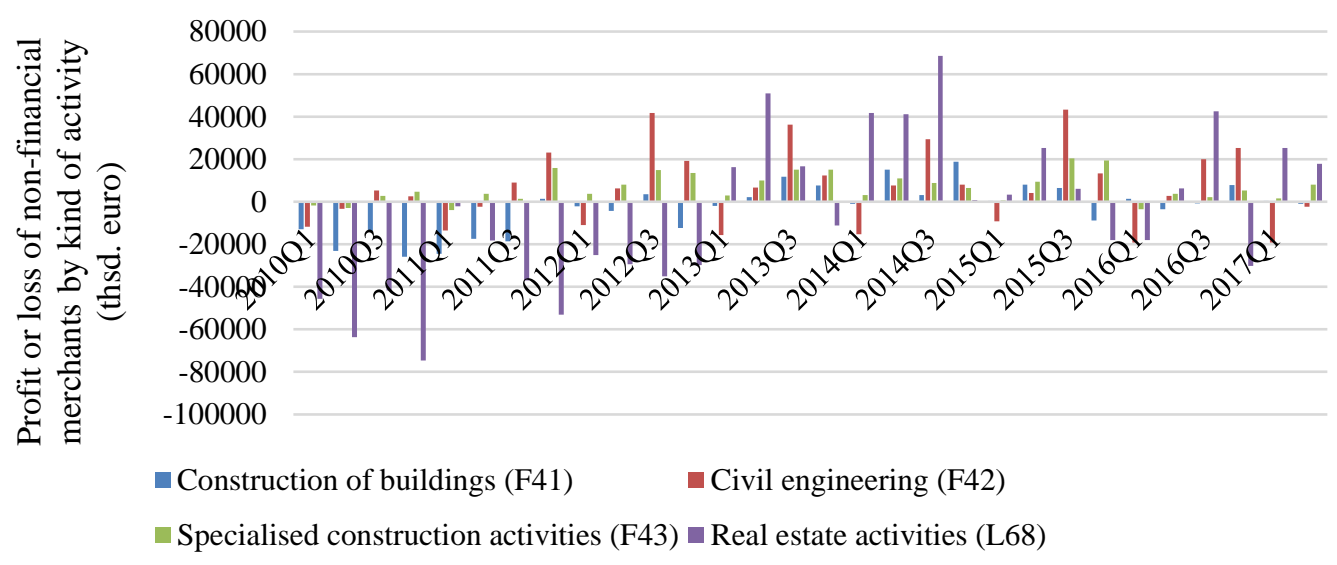

Fig. 3. Profit or loss of merchants (commercial companies) by the kind of activity (NACE Rev.2) (thsd. euro). Data: Central Statistical Bureau of Latvia (n.d.).

(Figure made by authors).

Most of housing stock in Latvia is located in Riga and Riga region. The total area of housing stock in statistical regions at the end of the year is shown in Fig. 4.

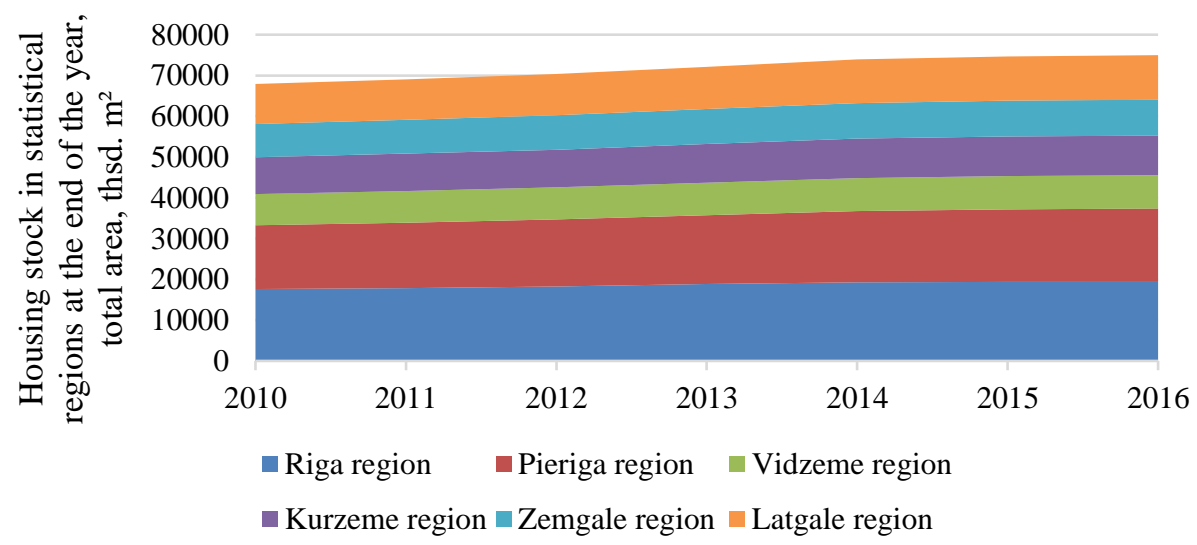

Fig. 4. Housing stock in statistical regions at the end of the year, total area, thsd. $\mathrm{m}^{2}$. Data: Central Statistical Bureau of Latvia (n.d.).

(Figure made by authors).

Figure 4 shows, that the biggest part of housing stock is situated in Riga region. The number of issued building permits is a part of real estate supply analysis. The number of building permits granted and the expected floor space in statistical regions and cities under state jurisdiction by sectors from 2010 to 2016 is shown in Table 4. 
Table 4. Number of building permits granted and the expected floor space in statistical regions and cities under state jurisdiction. Data: Central Statistical Bureau of Latvia (n.d.). (Table made by authors)

\begin{tabular}{|l|r|r|r|r|r|r|r|}
\hline & \multicolumn{1}{|c|}{$\mathbf{2 0 1 0}$} & \multicolumn{1}{c|}{$\mathbf{2 0 1 1}$} & \multicolumn{1}{c|}{$\mathbf{2 0 1 2}$} & \multicolumn{1}{c|}{$\mathbf{2 0 1 3}$} & $\mathbf{2 0 1 4}$ & $\mathbf{2 0 1 5}$ & $\mathbf{2 0 1 6}$ \\
\hline $\begin{array}{l}\text { One-dwelling } \\
\text { buildings }\end{array}$ & 245.4 & 258.0 & 293.8 & 310.2 & 313.2 & 282.0 & 250.3 \\
\hline $\begin{array}{l}\text { Summer houses and } \\
\text { weekend houses }\end{array}$ & 25.0 & 18.6 & 29.4 & 22.7 & 26.2 & 23.2 & 15.1 \\
\hline $\begin{array}{l}\text { Two and more } \\
\text { dwelling buildings }\end{array}$ & 146.1 & 181.5 & 139.6 & 301.1 & 95.2 & 34.8 & 102.8 \\
\hline $\begin{array}{l}\text { Residences for } \\
\text { communities }\end{array}$ & 0.3 & 0.0 & 0.3 & 4.4 & 15.4 & 0.0 & 0.9 \\
\hline $\begin{array}{l}\text { Hotels and similar } \\
\text { buildings }\end{array}$ & 6.5 & 14.3 & 40.5 & 27.1 & 36.5 & 29.3 & 13.5 \\
\hline Office buildings & 7.9 & 89.8 & 17.1 & 62.2 & 19.4 & 11.8 & 31.9 \\
\hline $\begin{array}{l}\text { Wholesale and retail } \\
\text { trade buildings }\end{array}$ & 258.9 & 58.5 & 91.2 & 74.7 & 84.8 & 26.5 & 9.6 \\
\hline $\begin{array}{l}\text { Traffic and } \\
\text { communication } \\
\text { buildings }\end{array}$ & 33.3 & 9.0 & 60.0 & 14.9 & 36.1 & 1.9 & 19.1 \\
\hline $\begin{array}{l}\text { Industrial buildings } \\
\text { and warehouses }\end{array}$ & 332.8 & 537.0 & 256.8 & 421.8 & 311.6 & 181.1 & 173.2 \\
\hline $\begin{array}{l}\text { Public entertainment, } \\
\text { education, hospital or } \\
\text { institutional care } \\
\text { buildings }\end{array}$ & 45.4 & 43.0 & 67.8 & 281.4 & 94.8 & 38.5 & 27.5 \\
\hline $\begin{array}{l}\text { Other non-residential } \\
\text { buildings }\end{array}$ & 294.8 & 489.2 & 340.8 & 319.1 & 235.1 & 243.7 & 199.0 \\
\hline
\end{tabular}

In 2016, the real estate market situation improved in spite of the unstable economic and political situation in the country, and the real estate market was still active in November 2016 - the number of transactions remained at the stage of growth, as well as the average prices of apartments continued to rise. "The total number of transactions from January 2016 until the end of November compared to situation in the last year increased by $12.88 \%$. Also, the average price index, which increased by $6.8 \%$ from the beginning of 2016, is a prerequisite for further market development" (Zariņs, 2016). In turn, the real estate market in Estonia after the crisis has been able to recover in a couple of years in all real estate segments; therefore, unlike in Latvia, it shows signs of stable development and allows the market participants to look with confidence in the future. The growth of the housing market in Estonia continued in 2016, but it was not too rapid.

In turn, the real estate market in Lithuania was rapidly developing, housing was revalued, and its prices were high. Due to the availability of bank financing and favourable interest rates, the demand for housing is increasing. Real estate market development trends in the transactions with residential areas in the Baltic States are shown in Table 5. 
Table 5. Real estate market development trends in the transactions with residential areas in the Baltic States in 2016 (table made by authors)

\begin{tabular}{|c|c|c|}
\hline State & \begin{tabular}{|l} 
Positive Factors \\
\end{tabular} & Negative Factors \\
\hline Latvia & $\begin{array}{l}\text { - demand for standard-type apartments will } \\
\text { increase both in new projects, standard-type } \\
\text { objects and old houses } \\
\text { - average price of standard-type apartments } \\
\text { increases } \\
\text { - average prices for new apartments remain } \\
\text { constant, the housing affordability index } \\
\text { increases } \\
\text { - volume of issued housing loans increases } \\
\text {-average interest rates on new housing loans } \\
\text { increase } \\
\text {-different price ranges for standard-type } \\
\text { apartments } \\
\text {-ALTUM program promotes the housing } \\
\text { demand } \\
\text { - wide range of investment objects } \\
\text {-household income (average salary and } \\
\text { minimum monthly wage) increases }\end{array}$ & $\begin{array}{l}\text {-household is mostly acquired } \\
\text { once or several times in a } \\
\text { lifetime } \\
\text {-real estate transaction is a } \\
\text { costly and lengthy process; } \\
\text { Land Register fee is } 2 \% \text { of } \\
\text { the transaction amount } \\
\text { - decline in the supply of } \\
\text { standard-type apartments } \\
\text { along with the increase in } \\
\text { prices } \\
\text {-accumulation of long-term } \\
\text { initial contribution } \\
\text {-natural growth of the } \\
\text { population is negative, and } \\
\text { there is the trend to decrease }\end{array}$ \\
\hline Lithuania & $\begin{array}{l}\text {-favourable bank financing - low interest rates } \\
\text { - arranged mortgage market } \\
\text { - arranged legislation on the loan granting by } \\
\text { assessing the possibilities for repayment of the } \\
\text { citizens } \\
\text { - wide range of apartments in the new project } \\
\text { offers } \\
\text {-increase in the average prices of new } \\
\text { apartments, increase in the housing } \\
\text { affordability index } \\
\text {-reduced opportunity to deal with the fictitious } \\
\text { amounts } \\
\text {-increase in household income (average salary } \\
\text { and minimum monthly salary) } \\
\text {-number of immigrants is rapidly growing } \\
\text {-increase in the demand for housing loans } \\
\text {-the lowest average interest rate on new housing } \\
\text { loans } \\
\text {-increase in the volume of granted housing loans } \\
\text {-wide range of investment objects in the offer }\end{array}$ & $\begin{array}{l}\text {-excessive real estate prices } \\
\text { - household housing is mostly } \\
\text { acquired once in a lifetime } \\
\text { - natural growth of the } \\
\text { population is negative, there } \\
\text { is the trend to decrease }\end{array}$ \\
\hline Estonia & $\begin{array}{l}\text {-favourable banking policy - low interest rates } \\
\text {-high level of granted loans } \\
\text {-increase in the demand for housing loans } \\
\text {-low average loan interest rates for new housing } \\
\text { loans } \\
\text {-increase in the volume of granted housing loans } \\
\text {-increase in the household income (average } \\
\text { salary and minimum monthly salary) } \\
\text { - wide range of investment objects } \\
\text {-increase in the average prices of new } \\
\text { apartments }\end{array}$ & $\begin{array}{l}\text {-household housing is mostly } \\
\text { acquired once in a lifetime } \\
\text { - apartment prices are rapidly } \\
\text { rising } \\
\text { - natural growth of the } \\
\text { population is negative, there } \\
\text { is the trend to decrease }\end{array}$ \\
\hline
\end{tabular}


The minimum wage has increased since 1 January 2016 in all three Baltic States. The average monthly gross wage in the first quarter of 2016 in Estonia was 1091 EUR, in Latvia - 827 EUR, and in Lithuania - 748 EUR (LETA, 2016).

In Latvia in 2016, the total number of transactions from January until the end of November increased by $12.88 \%$, compared with the situation in the past year. Also, the average price index increased by $6.8 \%$ from the beginning of 2016, which is a prerequisite for further market development (Zariňš, 2016). The research of Zarinšs (2016) suggests that the development of the real estate market in the residential segment in Lithuania was very active in 2015. The number of transactions increased by $16 \%$ compared to 2014 , and 810 sales transactions with apartments and 70 sales transactions with private houses on average were implemented each month. In 2016, the number of inhabitants in Vilnius increased, hence the number of transactions in the housing market also increased reaching a record high number of transactions - 450 (LETA--BNS, 2017).

In 2015, the Estonian real estate market continued to grow; however, the growth was not very rapid. In 2015, the average price for apartments in Tallinn increased by $3.8 \%$ and reached $1556 \mathrm{EUR} / \mathrm{m}^{2}$. In December 2015, the number of real estate transactions increased by $16 \%$. The prices of old standard-type apartments in the residential areas stabilized, while the prices of new project apartments increased by $10 \%$ to $15 \%$. In turn, the average price of apartments in Tallinn increased by $12.2 \%$ and reached 1746 EUR/m² in December 2016 (OberHaus Real Estate Advisors, 2017). According to Ober-Haus Real Estate Advisors' data (2016), $40 \%$ of transactions took place without a bank loan also in 2016, and, in general, $10 \%$ to $20 \%$ of the apartments were purchased as an investment; new project apartments cost $2300 \mathrm{EUR} / \mathrm{m}^{2}$ to $5000 \mathrm{EUR} / \mathrm{m}^{2}$ in the city center and $1500 \mathrm{EUR} / \mathrm{m}^{2}$ to $2200 \mathrm{EUR} / \mathrm{m}^{2}$ in residential areas. The apartment prices in Estonia are fluctuating, mainly due to their location. Most transactions in 2016 were implemented in the city center, and the apartments in good condition or in the renovated buildings were mostly demanded, with prices from $2000 \mathrm{EUR} / \mathrm{m}^{2}$ to $2900 \mathrm{EUR} / \mathrm{m}^{2}$.

In general, there are several positive trends in the Baltic States that contribute to the real estate market development. One of the most significant trends is the increase in demand in the housing segment, household income growth, and low interest rates. Population growth is also a significant factor, as well as the wide range of the investment objects being offered.

\section{CONCLUSION}

The impact of investments on the real estate market is currently high in all Baltic States. When attracting the investors, the state has the opportunity to develop the real estate market and to create a high-quality housing supply and an appropriate solvent demand. The authors make the following conclusions:

1) The real estate market in Latvia as well as in Estonia is currently on an upward trend. The situation in Latvia has improved since 2016, the number of transactions is increasing, and the average prices of apartments are gradually increasing. The rental market in the residential segment in 
Estonia was less active, while transactions were frequent in the housing market. The real estate market in Lithuania is stable.

2) The number of transactions in 2016 reached a record-high index in the latest period. The development of the real estate market contributes to the development of the national economy, thus creating a favourable investment climate for the investors. By assessing the real estate market situation in the Baltic States, it can be concluded that the most favourable conditions in the housing segment are in Estonia. Currently, real estate market in Estonia demonstrates the signs of stable development in all segments, and the market participants allow looking forward with the confidence to the future.

3) The Estonian housing market continues to grow, but its growth is not very fast. According to indicators, this segment is close to the peak phase of the pre-crisis real estate market development. Housing rental market is less active, while the deals are actively concluded at the housing market activity, which is promoted by favourable banking policies - loan rates are low, similar to pre-crisis rates, and this is beneficial to mortgage borrowers who continue to cover their liabilities. Lithuanian experts conclude that taking into account the overall demographic situation, it appears that it is not favourable.

As was researched in the article, real estate market is being influenced by variety of factors, and supply and demand analysis is a multistep process. The positive and negative real estate market influencing factors in Baltic States are identified in article as well. It may be recommended to policy makers to provide a favourable investment climate for the investors that can positively influence real estate market development. At the same time, the housing affordability promoting activities should be stimulated as well, and sustainable development of the real estate market and national should be promoted.

\section{REFERENCES}

Arco Real Estate. (n.d.). Tirgus pārskati [Real Estate Market Overview]. Retrieved from http://www.arcoreal.lv/lv/tirgus-parskati/latvija/

Balsts. (n.d.). Nekustamo īpašumu tirgus prognoze 2017. gadam [Real Estate Market Forecast for 2017]. Retrieved November 7, 2017, from http://www.balsts.lv/lat/jaunumi/?doc=1412

Baltic Sotheby's International Realty. (2015). Baltijas attīstītāju forumā analītik̦i vērtēs ekonomisko indikatoru ietekmi uz nekustamā ìpašuma tirgu [Analysts at the Baltic Developers Forum will Evaluate the Impact of the Economic Indicators on the Real Estate Market]. Retrieved October 30, 2017, from http://balticsothebysrealty.com/lv/baltijas-attistitaju-foruma-analitiki-vertesekonomisko-indikatoru-ietekmi-uz-nekustama-ipasuma-tirgu/

Central Statistical Bureau of Latvia. (n.d.). Statistic Database. Retrieved October 27, 2017, from http://www.csb.gov.lv/dati/statistikas-datubazes-28270.html

Colliers International. (2017a). Baltic States. Property Snapshots. Research \& Forecast Report (2017). Retrieved August 15, 2017, from http://www.colliers.com//media/files/emea/latvia/research/2017/colliers_baltic_quarterly_report_1q17_sec.pdf

Colliers International. (2017b). Baltic States. Investment Market. 1 HY 2017. Research and Forecast Report. Retrieved from http://www.colliers.com/en-lv/-/media/files/emea/latvia/research/2017/ colliers_investment-market-baltics-1hy2017_final_sf.pdf 
Eurostat. (n.d.) European Statistics Database. Retrieved from http://ec.europa.eu/eurostat/data/database

Geipele, I., Kauškale, L., Lepkova, N., \& Liias, R. (2014). Interaction of Socio-Economic Factors and Real Estate Market in the Context of Sustainable Urban Development. In 9th International Conference "Environmental Engineering 2014" (pp. 1-8). Lithuania, Vilnius, May 22-24, 2014. Vilnius: Vilnius Gediminas Technical University Press Technika. ISBN 9786094576409. e-ISBN 9786094576904. e-ISSN 2029-7092. https://doi.org/10.3846/enviro.2014.117

Hui, E. C. M., \& Chan, K. K. (2014). Foreign Direct Investment in China's Real Estate Market. Habitat International, 43, 231-239. https://doi.org/10.1016/j.habitatint.2014.04.007

Kauškale, L., \& Geipele, I. (2016). Influence of Economic and Real Estate Market Fluctuations on Real Estate Entrepreneurship in Latvia. In Proceedings of the Sixth International Conference on Industrial Engineering and Operations Management (pp. 851-862). Malaysia, Kuala Lumpur, March 8-10, 2016. Kuala Lumpur. ISBN 9780985549749. ISSN 2169-8767. Scopus Code 135628.

Latio. (2016). Mājokḷu tirgus pārskats Rīga un regioni. 2015. gada IV ceturksnis [Housing Market Overview, 4th quarter of 2015]. Retrieved from http://latio.lv/lv/pakalpojumi/tirgusanalize/majoklu-tirgus/138/latio-majoklu-tirgus-parskats-2015-q4-final.pdf

LETA. (2016, May 30). Algu ziņā Igaunija strauji atraujas no Latvijas [Estonia is Rapidly Establishing a Lead over Latvia in Terms of Wages. Retrieved from http://www.infotop.lv/article/lv/algu-zina-igaunija-strauji-atraujas-no-latvijas

LETA--BNS. (2017, January 20). Lietuvā nav vienisprātis, vai tirgū neveidojas nekustamā ìpašuma burbulis [There is no Consensus in Lithuania on Whether the Real Estate Bubble is being Formed on the Market]. Retrieved from http://financenet.tvnet.lv/zinas/644130lietuva_nav_vienpratibas_vai_tirgu_neveidojas_nekustama_ipasuma_burbulis

Ober-Haus Real Estate Advisors. (2016). Real Estate Market Report Baltic States 2016. Retrieved December 15, 2016, from http://www.ober-haus.lv/wp-content/uploads/2017/03/Ober-HausMarket-Report-Baltic-States-2016\%20(3).pdf

Ober-Haus Real Estate Advisors. (2017). Real Estate Market Report Baltic States 2017. Baltic States Capitals: Vilnius, Riga, Tallinn. Retrieved April 27, 2017, from http://www.ober-haus.lv/wpcontent/uploads/2017/03/Ober-Haus-Market-Report-Baltic-States-2017.pdf

Ober-Haus Real Estate Advisors. (2015). Latvijas dzīvojamo platību tirgus komentāri [Comments on the Residential Real Estate Market in Latvia]. Retrieved April 25, 2017, from http://www.oberhaus.lv/wp-content/uploads/2016/02/Dzivojamas_platibas_4_cet_2015_LV.pdf

Rudzītis, E., \& Martinsone, K. (2015, June 5). SEB: mājoklı pieejamība nedaudz mazinājusies visās trijās Baltijas valstīs [SEB: Housing Affordability has Fallen Slightly in all Three Baltic Countries]. Retrieved April 25, 2017, from http://www.seb.lv/jaunumi/2015-06-05/seb-majoklupieejamiba-nedaudz-mazinajusies-visas-trijas-baltijas-valstis

Rudzītis, E. (2016, September). Real Estate Market Affordability Index [Mājokḷ pieejamības indekss]. Retrieved from http://www.seb.lv/sites/default/files/web/files/ webstorage/mpi/HAI_Baltics2Q2016.pdf

Šečkutè, V., Semjenovs, A., \& Isküll, S. (2016, March 8). Baltijas mājokḷu pieejamības indekss [Housing Affordability Index in Baltic States]. Retrieved April 12, 2017, from https://www.swedbank-research.com/latvian/baltijasmajoklu/2016/q1/hai_final_lv_2015_4q.pdf

Vanags, J. (2010). Nekustamā ìpašuma ekonomika [Real Estate Economics]. Riga: RTU Press.

Zariņš, A. (2016, December 6). Darījumu skaits gada laikā palielinājies par 12,88 \% [The Number of Transactions has Increased by $12.88 \%$ over the Year]. Retrieved from http://www.city24.lv/lv/nekustama-ipasuma-zinas/8378/darijumu-skaits-gada-laika-palielinajiespar-1288 


\section{AUTHORS' SHORT BIOGRAPHIES}

Inese Binovska, Mg. oec., obtained the Bachelor of Social Sciences degree in management in 2006. In 2017, she with excellent results obtained the Professional Master's degree in construction business and real estate management and earned the qualification of a real estate economist. She participated in the 58th RTU international scientific conference where she received an acknowledgment for her thesis. I. Binovska is currently a User Specialist at the IT company AS "Rix Technologies". The main areas of her research are real estate market analysis, and trends in residential and commercial market development in the Baltic States.

Linda Kauškale, Mg. oec., is a Lecturer, a PhD student and Researcher within the Institute of Civil Engineering and Real Estate Economics, Faculty of Engineering Economics and Management, Riga Technical University. She with distinction obtained the Professional Master's degree in civil construction and real estate management and has the qualification of a real estate economist as well as extensive practical experience. She has participated in international scientific conferences and seminars in Latvia, Germany, United Arab Emirates, Singapore, Malaysia, Lithuania, etc. Her main research areas are sustainable real estate market concept, sustainable cities and sustainable construction, green buildings, macroeconomic analysis, business cycle, decision-making, environmental development problems, etc. She is a DGNB (Deutsche Gesellschaft für Nachhaltiges Bauen - German Sustainable Building Council) Registered Professional. In 2016, she was a Professional Member of Industrial Engineering and Operations Management Society. In autumn 2016, she was a Deutsche Bundesstiftung Umwelt (German Environmental Foundation) Scholarship holder. In autumn 2013, she was a FIABCI Scholar.

ORCID iD: https://orcid.org/0000-0002-0280-2977

Jānis Vanags is a Professor of the Faculty of Engineering Economics and Management at Riga Technical University (RTU). He received the Doctoral degree in economics from RTU in 2004. His research and teaching interests include national economics, engineering economics, building management, real estate economics, microeconomic and macroeconomic processes, real estate management, and sustainable development. At present, J. Vanags teaches undergraduate and postgraduate courses in national economics, finance market, and real estate economics at RTU. ORCID iD: https://orcid.org/0000-0002-7570-5457 